\section{THE MICROSCOPE}

ThE value of Nitrate of Silver as a Reagent for deMONSTRATING MINUTE STRUCTURE.- Since VOn Recklinghausen drew attention to the beautiful results to be obtained by the use of a weak solution of nitrate of silver, in the study of the finer distribution of vessels, and especially of the lymphatics, much discussion has taken place as to the trustworthiness of results obtained by this method, and there are some histologists of merit who maintain that the whole thing is false and delusive in its effect. The method consists in immersing perfectly fresh (warm from the animal) tissues in a $\frac{1}{2}$ per cent. aqueous solution of nitrate of silver, leaving them there for from five to ten minutes, and then, after thorough washing, mounting in glycerine, and exposing to sunlight for half an hour, or two or three hours as the case may be. If desired, the tissue may be plunged while fresh into serum (nreserved with just a trace of iodine), and after two hours' maceration therein may be smoothed with a small paint-brush, to remove superficial epithelium (as, for instance, in the centrum tendineum of the guinea-pig), and then placed in the silver solution. It is, however, preferred by Dr. Klein, of Vienna, to bush away the superficial epithelium of the thoracic surface, if the lymplatics of the centrum tendineum are to be examined, lefore removing the diaphragm from the body, whilst perfectly fresh and warm, warm water being used for this purpose, and a. camel's-hair paint-brush : immediately after this "pencilling" the centrum tendineum is cut out and placed in the nitrate of silver solution. In the same way, in researches on the cornea the conjunctival epithelium may be removed in the living animal and the silver solution then applied. Dr. Klein, Professor Stricker's assistant, has found that the best results were to be obtained with the cornea, by removing the conjunctival epithelium, and rubbing the corneal surface well with Iunar caustic, and removing the cornea in half an hour's time. This method proves admirable with frogs, and is probably applicable to other cornex. The results of the nitrate-of-silver-staining as seen in the centrum tendineum, are that both thoracic and peritoneal epithelium (where not pencilled away) are stained, the outlines of the cells being brought out very distinctly. In addition to this the epithelium lining the vessels which run in the centrum is also brought out, and especially the curiously crenated epithelium of the fine lymphatics is demonstrated. Moreover, Recklinghausen pointed out that small branched cavities become delineated connected by their branches to one another, and opening into the lymphatics with the crenate epithelium. These lacunar channels, "the juice canals," are brought into view by the action of the silver in staining the substance of their walls but leaving the cavity free. A successful silver preparation of the centrum tendineum of a guinea-pig, for instance, show's these structures clearly, but it is not always possible to succeed. Besides the remarkable epithelium of the lympliatics and the juice-canals, a hexagonal parement of enormous cells is demonstrated on the nerve sheaths, and an exceedingly fine cell pavement on the adventitia of the small veins in some beautiful silver preparations of the "centrum " made by J). Burdon Sanderson. The results in the cornea are very remarkable, for the whole substance of that tissue in the frog is demonstrated to be filled with oblong radiating cavities, communicating with one another by their branches, and of so angular and regular a character as to give the appearance of a mosaicwork or some such elaborate device. These cavities correspond to the juice-canals in the centrum tendineum, it is by their means that the cornea is nourished, it is they which contain the large star-like cells or protoplasm-masses brought out by gold chloride, and it is along their branches that the divided portions of these cells wander so remarkably in the process of inflammation. And now we are told by some persons that these are artificial productions, that the juice-canals and the radiate lacunæ, and the crenate lymphatic epithelium too, are due to fortuitous coagulation caused by the silver, that they do not represent structures existing in life. There are two sets of objectionists, some who deny the whole thing, others who go so far as to deny the juice-canals and stellate lacunæ, but admit the epithelium. An exponent of the first order is a certain Dr. Robinski, who in a paper published in the excellent Archives de Physiologie of Brown. Séquard, pretends that the crenate epithelium which so many have seen in the finer lymph vessels, as well as the juice. canals, are due to imperfect retention of portions of the superficial epithelium, and gives a drawing intended to show this. The author of the paper has simply failed utterly and entirely in using the method, and the outrageous view which he advances does not require refutation. Everyone knows who has made silver preparations successfully that the thoracic, the lymph-canal, and the peritoneal epithelium may all be seen lying one over the other in parts of a preparation, and that the form of the second prevents its being mistaken for the first or third. Others maintain that the crenate lymph-epithelium is simply a form due to the silver, and not to cells at all. This is impossible, because the nucleus and cell-contents are sometimes clearly demonstrated, and moreover the same form of epithelium may be readily obtained from large lymph-sacs, of some of which it is characteristic. The juice-canals, if they appear doubtful at all when taken by themselves (which indeed they do not if a good preparation is examined), when seen in the light of the stellate lacunze of the frog's cornea, are clearly understood, and must be fully admitted as normal living structures. There are, however, persons who object to these, among whom is so eminent a bistologist as Professor Schweigger-Seidel, and also that accomplished micrographer, Dr. Ranvier, of Paris. They actually hold that these forms are post-mortem products, the effect of the action of nitrate of silver on the albumen and gelatine of the tissue. It is almost as strong a position to take up as that of certain schoolmen who maintained that we know rothing of the anatomy of living animals, since the air admitted on cutting them open, and the scissors, produced all the various viscera seen in a dissection. There are some strong facts which we have witnessed which render such a view untenable. In the first place, the stellate lacunæ of the frog's cornea are shown in a preparation in our possession, with the intermediate substance stained by gold and the lacunx and cells unstained, in fact, exactly the same appearance as is produced with silver. Hence the stellate form of the lacunze cannot be due to a specific action of the silver. Again, by silvering the living cornea whilst it is still part of the frog, the structure is brought out, and may be obtained of all degrees of intensity, the form, however, always remaining the same, and not varying with the amount of silver allowed to act on it, as might be expected had we to do with a precipitation-form, which should appear less completely developed when less silver is used. Moreover, the living cells were thus demonstrated lying in these stellate lacunx, creeping up the radiating branches, drawing back again, and creeping along others, thus obtaining that curious direction to their morements which one always observes in studying them in the fresh, unstained, inflamed cornea. The necessity of admitting that the normal structure of the frog's cornea is brought out by the silver method, covers also the question as to the similar structures in the centrum tendineum. The "Saft-canälchen" must equally be admitted as having a living existence, and are not due to the imaginary precipitating action of nitrate of silver on some albuminoid, as SchweiggerSeidel would have us believe, but a parallel to which he cannot find. The chief difficulty with regard to the crenate epithelium of the lymph vessels in the centrum tendineum is to explain why we only see one layer of these cells; they should appear all round the wall of the vessel so as to produce a double layer as we look through it, but we only see one layer, the other not being stained. The action of light, the absorption of the silver, and other causes, may be hazarded as explanations of this ; but it would be satisfactory to get a double layer clearly shown.

So far, then, from agreeing with Schweigger-Seidel and other objectors, that the silver method of Von Recklinghatsen "gives no true indication of the structure of the cornea, nor of similar structures, and "should be abandoned,"* we believe that when carefully applied it furnishes most admirable results, difficult to attain in any other way at present in our hands, and is worthy of all confidence, and should be used as a means of investigation in other. structures besides those to which it has been already applied.

E. R. L.

REPORT OF THE KEW COMMITTEE OF THE BRITISH ASSOCIATION FOR THE ADVANCE. MEN'T OF SCIENCE FOR I869-70

THE Committee of the Kew Observatory submit to the Council of the British Association the following statement of their proceedings during the past year :-

At the meeting of the General Committee at Exeter it was re* Berichte der Math. Phys. Classe der Kön. Sachs. Gesellsch. x869. p. 352. 